\title{
Computer Games and Digital Media for Promoting Awareness of Civic Education: A Case Study of Some Critical Problems in Thailand
}

\author{
Amnart Pohthong, Alwanee Samoh, and Hanuna Hengtakaeh
}

\begin{abstract}
Nowadays, there are many seemingly unsolvable problems around the world. Some of these problems are caused by a lack of early education on civic responsibilities that leads to people with a lack of understanding of the need for discipline, a lack of ethics, misunderstanding, misleading, and mistrust of democracy. In addition, this is exasperated by the need for competition of natural resources and lands. Children at a young age, should be exposed to civic education and encouraged to practice what is taught about their civic responsibilities, especially during their elementary level in primary schools. At present, new generations in Thailand, including many leaders at several levels tend to pay little attention to civic education. Courses and activities that provide knowledge and practice about civic education are of little concern for inclusion in curricula and classrooms at most levels of Thai educational systems. In order to begin to address these problems, the study reports on the possibility of using computer games and digital media to encourage pupils to understand about civic educations in some focused topics that involve some current critical issues in Thailand such as an understanding and respect for traffic laws, discipline in schools, and waste disposal management. The consequent results of these problems lead many serious difficulties to most Thai communities. Our proposed computer games and digital media can be used as learning support in classrooms and for civic education self-learning outside classrooms.
\end{abstract}

Index Terms - Civic education, computer game, digital media, school discipline, traffic law, waste disposal management.

\section{INTRODUCTION}

Many problems around the world nowadays are caused by less discipline, less ethics, less responsibility of people. Road accidents and environmental damages are some examples of many critical problems affecting our lives today and in the future. Thailand and many countries face these problems. Road accidents are very high, especially at specific times of holiday periods each year. The consequences of road accidents affect not only the injured people but also their relatives and other people in their society. The Thai government has spent a lot of money to try to cope with these problems as well as other environmental problems. The rapid growth of human and car populations makes road accidents and environmental problems more critical. These problems

Manuscript received February 3, 2014; revised March 20, 2014.

Amnart Pohthong is with the Department of Computer Science, Faculty of Science, Prince of Songkla University, Hat Yai, Songkhla, 90110, Thailand. (e-mail: amnart.p@psu.ac.th).

Alwanee Samoh and Hanuna Hengtakaeh are with Faculty of Science, Prince of Songkla University, Hat Yai, Songkhla, 90110, Thailand (e-mail: comacc@hotmail.com, keesongsai_19@hotmail.com). cannot be solved only by laws but the country should reinforce young people's attitudes to help them to understand the related laws, practices, and the consequent results.

These problems are only some issues that should be paid more attention by most people. Thai people should find suitable ways to solve them. Thailand still has many critical problems to be solved such as the use of serious drugs and narcotics by the new generation, alcohol addiction, the growth of birth rate and abortion, political conflicts among people, corruption among politicians and officers, misunderstandings and misleading of democracy among some leaders and people. Moreover, the gap between the poor and the rich, the higher living costs, and the problems of globalization, add more critical problems to communities. Most problems are caused by less awareness and less practice of civic education during the development stages of young people.

At present, computer and information technologies have become popular technologies to support learning in many activities. Computer games and digital media have been successfully used for education and learning [1], [2]. Today, computer games are popular software used by many pupils in schools and students in universities. Their use has had a significant impact on society's learning. Therefore, this study aims to educate pupils about their responsibilities to become aware of civic education in such selected cases as discipline in schools, traffic regulations and laws, as well as waste disposal management and care of the environment.

\section{The Role AND INFLUENCE OF CiviC EdUCATION FOR DEVELOPING COUNTRIES}

\section{A. The Role of Civic Education for Learning and Practice}

Thailand has been defined as a developing country for quite a long time. The country's former leaders, government, and support teams have tried in many ways to improve people's living standards. However, most budgets have been used for building infrastructures such as transportation systems (roads, railways, and airports) while a few budgets have been used for education systems. Previously, a long times ago, many topics related to civic education were in the national curricula at lower and upper-primary schools. Some secondary schools were also concerned with civic education as teaching topics and did devote learning activities in their curricula. Therefore, at that time pupils could practice and carry out self learning projects for civic education. Nowadays, some countries manage civic education as a part of a disciplinary curriculum while some countries manage it as a part of a non-disciplinary 
curriculum [3]-[5]. Recently, some universities in Thailand have added civic education as a topic in some courses or as a whole course after having been taught about current problems in the country.

\section{B. The Influence of Civic Education for Developing Countries}

Nowadays, Thailand has many problems. Societies and communities have become very complicated partly because of the growth of populations, the problems of globalization and immigration to the country in both legal and illegal ways, as well as the rapid growth of information and communication technologies. Therefore, there are a lot of conflicts of interests among people in the country. Thailand has faced political problems for a long time. Currently, political problems not only cause conflicts due to the vested interests among people, but also affect the country in many ways such as its economy, tourism, security and maintaining a safe environments for living. In addition to political problems, there are still so many critical problems that make the country's slow progress. These problems have been mainly caused by a lack of knowledge that can help people to become good citizens. Thus, civic education is very important for developing countries [6]. Civic education can be used to resolve or reduce some problems in the country. For example, if most Thai people become more honest, corruption in the country will be less. Civic education is often related to knowledge and practice about social responsibility, self responsibility, equality, human rights, morals and ethics, and respect for laws and regulations [7],[8].
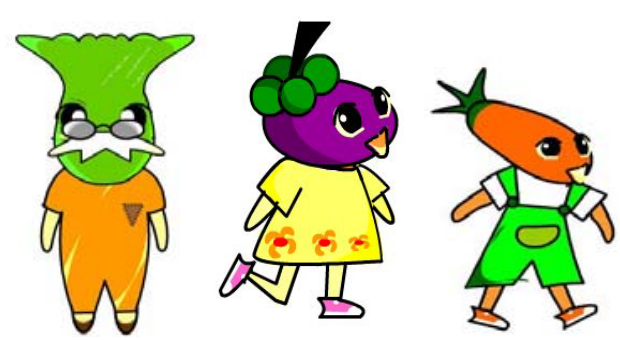

Fig. 2(a). (b). (c). Pakkard, mangkut, and carrot.

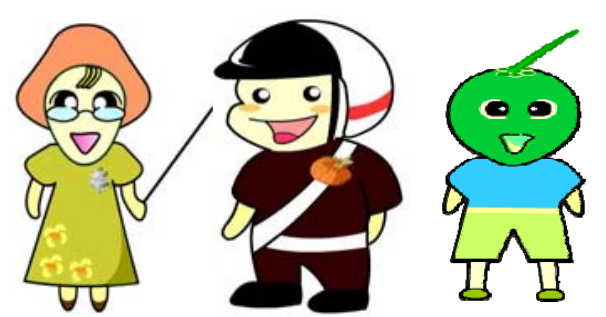

Fig. 2(d). (e). (f). Mali, fukthong, and maprow.

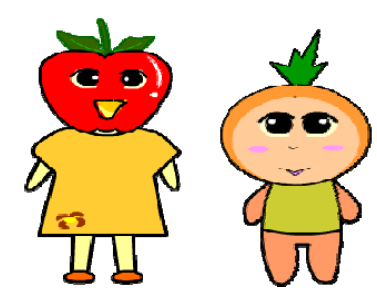

Fig. 2(g). (h). Apple and shom.

\section{COMPUTER-BASED LEARNING AND DigITAL MEDIA}

Computer and information technologies have been recognized for their usefulness and support many activities in most organizations around the world. They have become a part of our daily life. During this information technology and virtual world era, together with the rapid growth of globalization, both computer hardware and software as well as communication applications on mobile equipment have influenced organizations in many ways. A lot of software applications and information systems have been developed. Computer games and digital media are one of the most popular software and materials among all ages of people. Most computer games and digital media are focused on their use for entertainment [9] while a few of them are concerned with teaching and learning in both classrooms and outside classrooms [1], [2], [10]-[13]. Both commercial and non-commercial computer games and digital media related to children's learning are very useful if they are used in proper ways. In addition to teachers, parents can become involve in their children's processes of learning [14], [15].

\section{A Case Study of Selected Critical Problems}

The selected critical problems in Thailand for our case study are to create computer games and digital media to tackle three problems that we think are related to civic education and have a consequent negative effect on Thai society. Three of these problems are school discipline, knowledge and practice involving traffic laws, and waste disposal management. These problems should be addressed and practiced from a young age. They are also suitable for the use for support from computers and digital media, especially in the form of computer game-based learning. Our scope of the definitions for the selected cases in terms of civic responsibilities and education are as follows:

1) School discipline refers to pupils' self control to do good things or behave in correct manner such as those involving honesty, responsibility, morality, awareness of equality and human rights, and respect for schools' norms and regulations.

2) Knowledge and practice about traffic laws refers to an understanding and respect for traffic regulations and rules, traffic signs and signals, and good manners while driving.

3) Waste disposal management refers to refuse collection and rubbish disposal in a proper way, and learning about the types of containers and bins.

\section{Analysis And Design of the Proposed Computer GaMES AND Digital MEDiA}

\section{A. A Conceptual Framework of the Proposed System}

Our conceptual framework of the proposed system is as shown as Fig. 1 Knowledge and practice was based on focused civic education criteria. Then, a case study of selected critical problems such as discipline in schools, traffic laws and rules, and waste disposal management was analyzed and used for the design of digital media and computer games. A system evaluation and learning evaluation was also planned. 


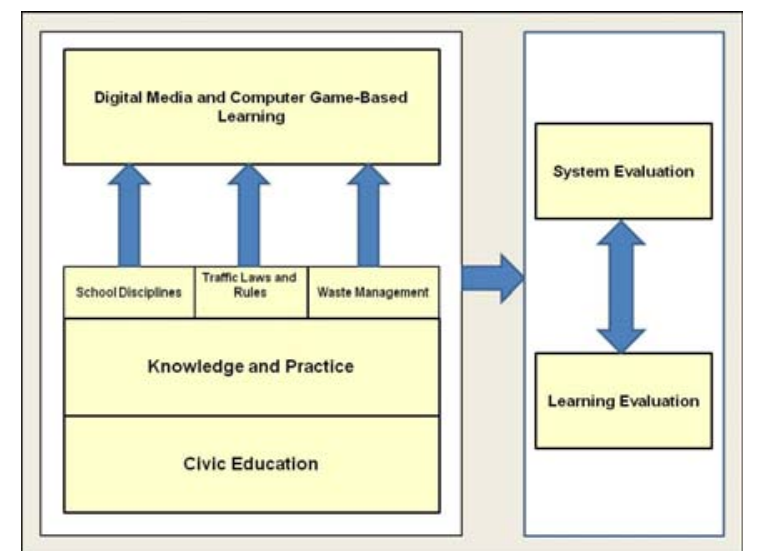

Fig. 1. A conceptual framework of the proposed system.

\section{B. Characters Analysis and Design}

Since the target groups are the young-age Thai citizens, especially pupils at the elementary levels in schools. Therefore, the characters and design of story boards were made to be simple to understand and be attractive for learning on our selected case study. Moreover, their enjoyment during use of the proposed system is also our concern. This would lead to learning engagement. The characters and stories were designed to be suitable for the Thai environment, styles and atmosphere. The story was based on the "Pakkard" family. They have one elder daughter, named "Mangkut", and one younger son, named "Carrot". The main characters are as follows:

1) A father, named "Pakkard" or a cabbage in English meaning, has his characteristics as a generous, kind, and good person as shown as Fig. 2(a).

2) A daughter, named "Mangkut" or a mangosteen (a local Thai fruit) in English meaning, has her characteristics as a tidy, humorous, and brilliant girl as shown as Fig 2(b). She often notices and observes most things that are surrounding her.

3) A son, named "Carrot" has his characteristics as a naughty, humorous, and stubborn boy as shown as Fig. 2(c).

4) A teacher, named "Mali" or a justmine flower (a local Thai flower) in English meaning, has her characteristics as a kind, and strict person as shown as Fig. 2(d).

5) A traffic policeman, named "Fukthong" or a pumpkin in English meaning, has his characteristics as a generous, kind, and helpful person as shown as Fig. 2(e). He often guides people about traffic laws.

6) A boy, named "Maprow" or a coconut in English meaning, has his characteristics as a naughty and selfish boy as shown as Fig. 2(f).

7) A girl, named "Apple" has her characteristics as a humorous girl as shown as Fig. 1(g) She often asks questions that she does not understand.

8) A girl, named "Shom" or an orange in English meaning, has her characteristics as a humorous girl as shown as Fig. 2(h). She often wakes up late and goes to her school late too.

\section{Story Process Analysis and Design}

Analysis and design of the learning processes using digital media and computer games for our selected cases are shown as the story boards in Table I - III respectively.

TABLE I: THE STORY BOARD DESIGN FOR LEARNING ABOUT DISCIPLINE IN A SCHOOL

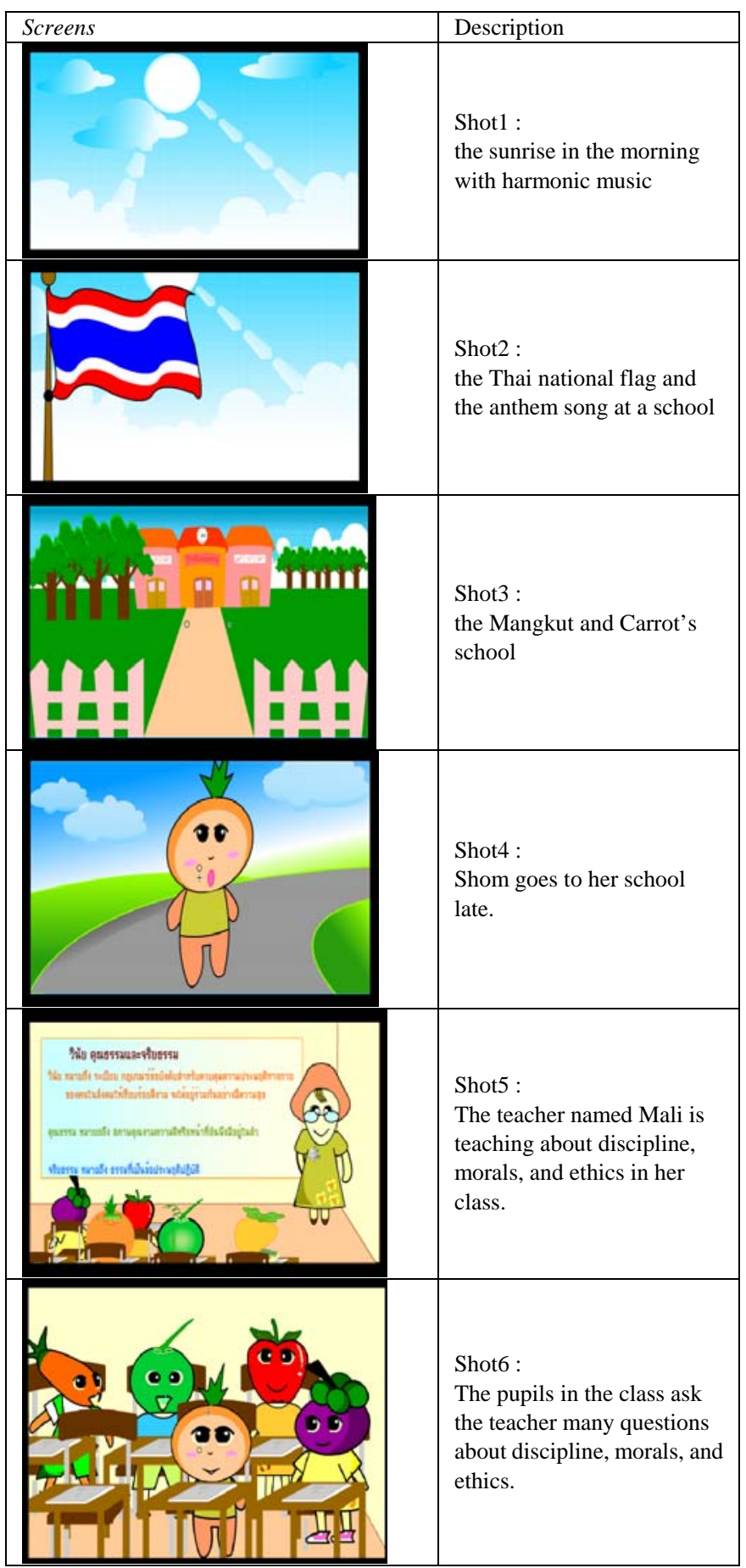

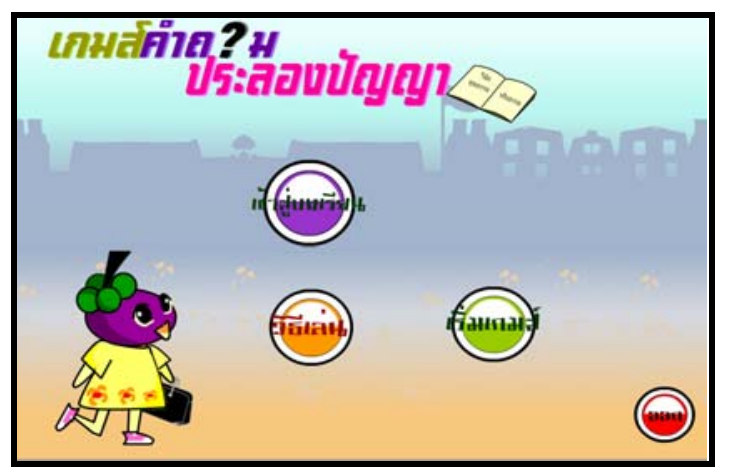

Fig. 3 . The computer game after learning the story from Table I. 
TABLE II: THE STORY BOARD DESIGN FOR LEARNING ABOUT TRAFFIC LAWS, REGULATIONS AND RULES

Sescription
$\begin{aligned} & \text { After school, Maprow } \\ & \text { and Carrot go back home. }\end{aligned}$

TABLE III: THE STORY BOARD DESIGN FOR LEARNING ABOUT WASTE MANAGEMENT ( GARBAGE DISPOSAL )

\begin{tabular}{|l|l|}
\hline Screens & $\begin{array}{l}\text { Shot1 : } \\
\text { Mangkut asks her father to go to } \\
\text { the sea. }\end{array}$ \\
\hline
\end{tabular}
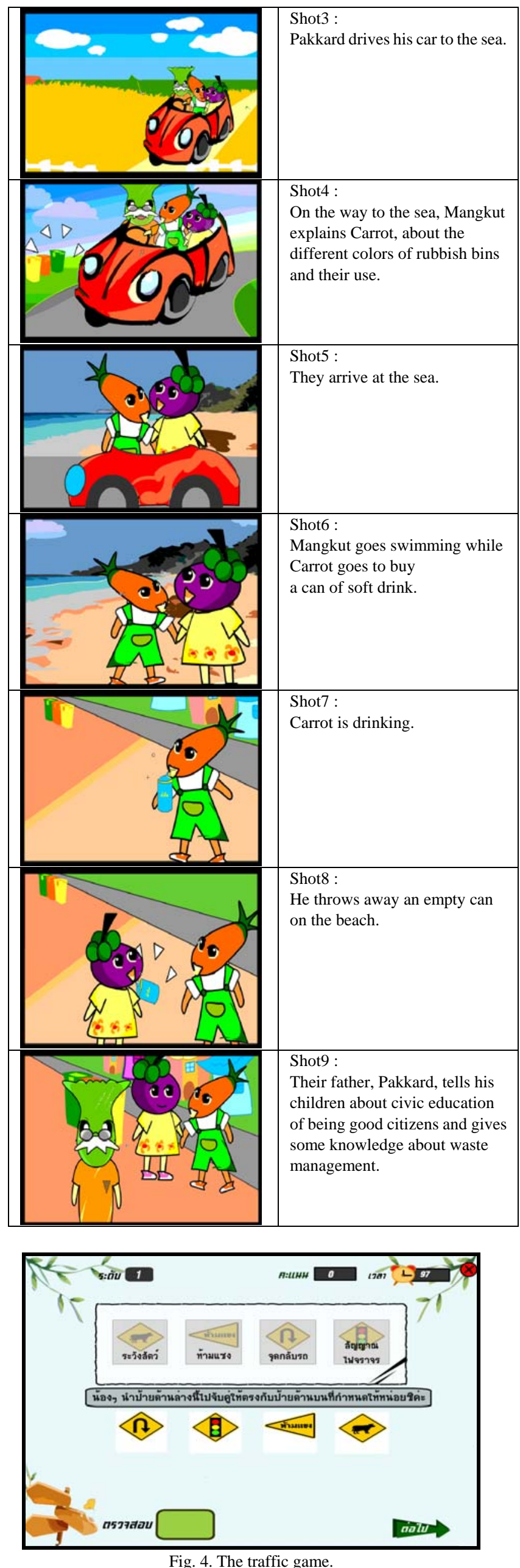


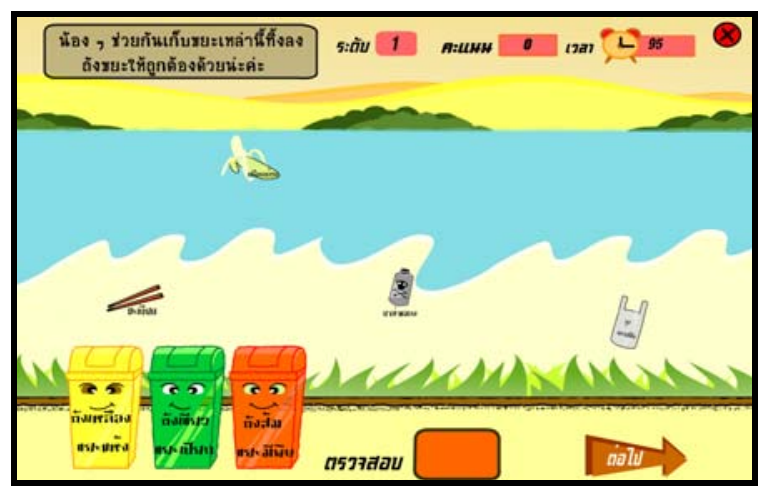

Fig. 5. The game of rubbish and rubbish containers matching.

Fig 3, 4, and 5 show the computer games after a player finishing his or her learning about discipline in a school, knowledge about traffic laws, regulations and rules, and waste management corresponding to the story boards demonstrated in Table I - III. The proposed computer games about traffic laws, regulations and rules, and waste management were designed to be simple for the target groups and also concerned with basic knowledge for their learning as well as attractive styles for their entertainment.

\section{SYSTEM IMPLEMENTATION}

From the proposed computer games and media designs, the system was developed corresponding to the structure chart as shown as Fig. 6 and its module explanation in Table IV.

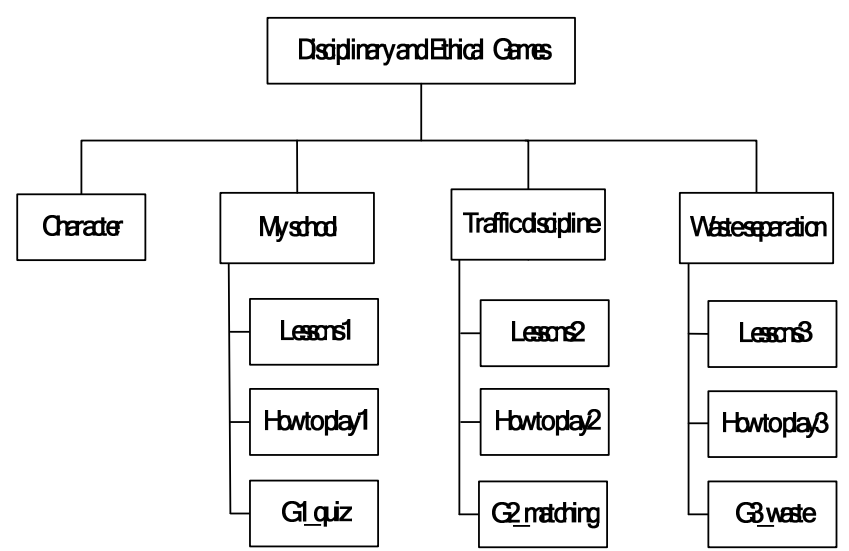

Fig. 6. The structure of the proposed system.

Fig. 7 and 8 show the logo of the proposed system and the main menu respectively while Fig. 9 shows the introduction of characters. These are only some example menus from the implementation of the proposed system.

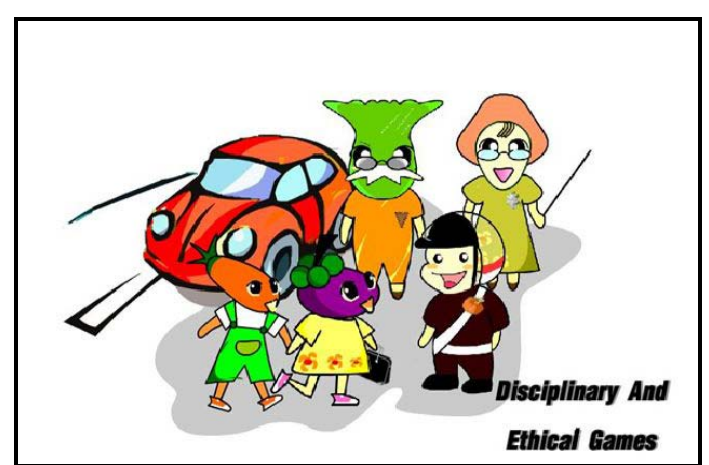

Fig. 7. The logo of the proposed system.

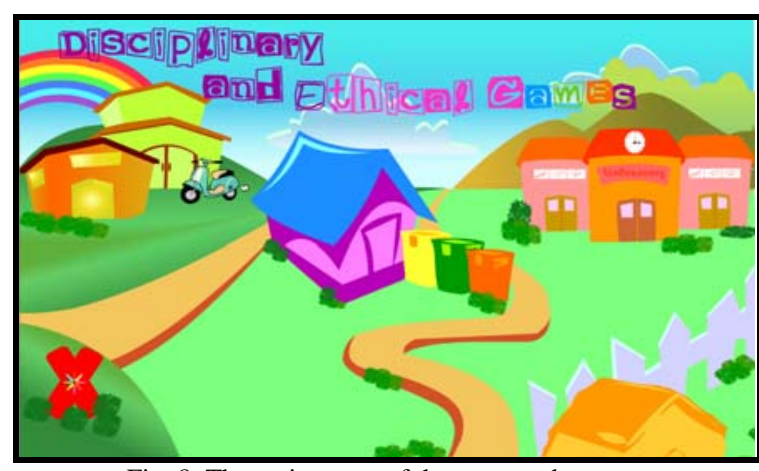

Fig. 8. The main menu of the proposed system.

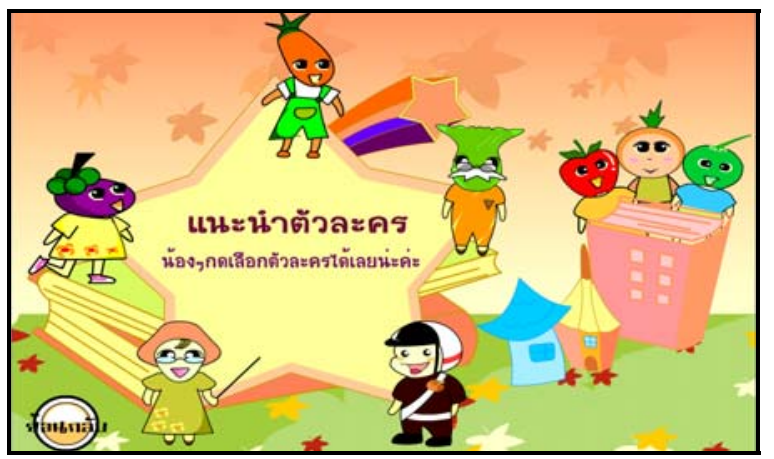

Fig. 9. The menu of characters' introduction.

TABLE IV: THE DESCRIPTION OF FUNCTIONALITY OF EACH MODULE

\begin{tabular}{|l|l|}
\hline \multicolumn{1}{|c|}{ Module Names } & \multicolumn{1}{c|}{ Description } \\
games & $\begin{array}{l}\text { The main menu consisting } \\
\text { of the following modules: } \\
\text { - the introduction of the characters } \\
\text { - My school } \\
\text { - Traffic disciplines } \\
\text { - Garbage management }\end{array}$ \\
\hline 2. Character & $\begin{array}{l}\text { The introduction of the characters } \\
\text { and their roles }\end{array}$ \\
\hline $\begin{array}{l}\text { 3. My school } \\
\text { 3.1 Lesson1 }\end{array}$ & $\begin{array}{l}\text { - the menu for learning about } \\
\text { discipline, morals and ethics using } \\
\text { digital media and animation }\end{array}$ \\
- the explanation about how to play \\
the first game \\
- the menu for the first game
\end{tabular}

\section{CONCLUSION}

The computer games and digital media were proposed in order to promote awareness of civic education related to critical problems currently affecting Thailand. The selected critical problems for a case study are based on learning and practice of some civic education at a young age about basic 
discipline in schools, traffic laws, regulations and rules, and waste disposal management. The target groups are pupils at the elementary levels in schools. However, an appropriate evaluation of the proposed system and its learning outcomes should be designed more precisely with the sample of target groups in future. The results of the system evaluation would lead to the system improvements. Then, knowledge and practice of civic education such as public and self responsibility, morals and ethics, democracy in terms of equality and human rights, as well as, respect for laws and regulations can be revised for the suitable critical problems. The digital media contents and computer game-based learning can be redesigned more practically for the target groups.

\section{REFERENCES}

[1] J. Robertson and C. Howells, "Computer game design: opportunities for successful learning," Computer \& Education, vol. 50, pp. 559-578, 2008.

[2] S. Chesney and C. Marcangelo, "There was a lot of learning going on using a digital medium to support learning in a professional course for new HE lecturers," Computer \& Education, vol. 54, pp. 701-708, 2010.

[3] F. Nogueira and A. Moreira, "A framework for civic education teachers' knowledge," Procedia- Social and Behavioral Sciences, vol. 47, pp. 1179-1183, 2012.

[4] T. S. Dee, “Are there civic returns to education?” Journal of Public Economics, vol. 88, pp. 1697-1720, 2004.

[5] M. Liu, "The development of civic values: case study of Taiwan," International Journal of Education Research, vol. 35, pp. 45-60, 2001.

[6] C. Tan, "Two views of education: Promoting civic and moral values in Cambodia schools," International of Education Development, vol. 28, pp. 560-570, 2008.

[7] V. E. Lake and I. Jones, "Service-learning in early childhood techer education: Using service to put meaning back into learning,” Teaching and Teacher Education, vol. 24, pp. 2146-2156, 2008.

[8] N. N. Duke, C. L. Skay, S. L. Pettingell, and I. W. Borowsky, "From adolescent connections to social capital: Predictors of civic engagement in young adulthood," Journal of Adolescent Health, vol. 44, pp. 161-168, 2009.

[9] X. Fang and F. Zhao, "Personality and enjoyment of computer game play,” Computers in Industry, vol. 61, pp. 342-349, 2010.

[10] B. Choi and Y. Baek, "Exploring factors of media characteristic influencing flow in learning through virtual worlds," Computers and Education, vol. 57, pp. 2382-2394, 2011.
[11] Y. C. Yang and W. Wu, "Digital storytelling for enhancing student academic achievement, critical thinking, and learning motivation: A year-long experimental study," Computers and Education, vol. 59, pp. 339-352, 2012.

[12] H. Ortegren, "The scope of digital image media in art education," Computers \& Education, vol. 59, pp. 793-805, 2012.

[13] S. Erthel, and E.Jamet, "Digital game-based learning: Impact of instructions and feedback on motivation and learning effectiveness," Computers and Education, vol. 67, pp. 156-167, 2013.

[14] P. Lacasa, L. Mendez, and R. Matinez, "Bringing commercial games into the classroom," Computer and Composition, vol. 25, pp. 341-358, 2008.

[15] J. Bourgonjon, M. Valcke, R. Soetaert, B. Wever, and T. Schellens, "Parental acceptance of digital game-based learning," Computers and Education, vol. 57, pp. 1434-1444, 2011.

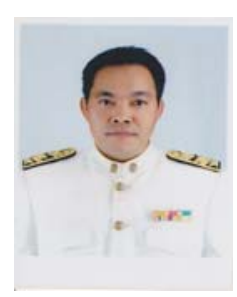

Amnart Pohthong was born in Trang, Thailand in 1959. He received his B.Sc. degree in mathematics in 1981; He received his M.Sc. in computer science in 1991. Both degrees are from Prince of Songkla University (PSU), Thailand. He received a Ph.D. in computer science in 2000 from Keele University, U.K. He has been working at PSU since 1983. Over the years he has held several positions and experienced in teaching, research, and administrative work. Currently, he is an assistant professor at the Faculty of Science, PSU. His research interests include software engineering, information systems, computer-based learning, and knowledge management.

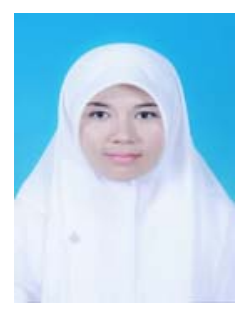

Alwanee Samoh was born in Pattani, Thailand in 1987. She received her B.Sc. degree in information and communication technology in 2010 from Prince of Songkla University, Thailand.

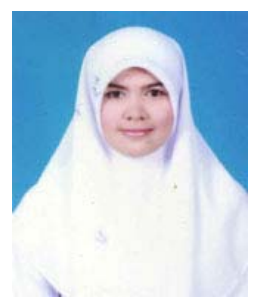

Hanuna Hengtakaeh was born in Yala, Thailand in 1987. She received her B.Sc. degree in information and communication Technology with second class hours in 2010 from Prince of Songkla University, Thailand. 